\title{
ENERGY SCENARIO OF THREE WHEELER ELECTRIC AND GASOLINE VEHICLE IN HETAUDA
}

\author{
Sabina Uprety ${ }^{1}$, Prof. Ram Chandra Sapkota ${ }^{2}$ \\ 1, 2 Department of Mechanical Engineering, Pulchowk Campus, Institute of Engineering, Tribhuvan University, \\ Nepal \\ Email Address: upretysabina@gmail.com,rc.sapkota1@gmial.com
}

\begin{abstract}
The global shifting away from petroleum fuels and towards more renewable energy sources has resulted in a significant progress in favor of vehicle electrification. The uptake of electric vehicle in the existing fleet of vehicles has positive impacts in the reduction of emissions and reduces the carbon footprints by moving in to greener transport. Nepal is a hydropower resource rich developing country; it can use its clean source of hydroelectricity for public transport electrification. Use of hydroelectricity for transport electrification can help to reduce the dependence on petroleum fuels with significant environmental benefits. This study aims to analyse energy scenarios of Hetauda through primary data survey of 4086 three wheeler as 1874 and 2212 as gasoline and electric respectively. Three scenarios are considered business-as-usual (BAU), ETRM 100 (100\% electric tempo replacement)and ETRM 75 (75\% electric tempo replacement). Energy demand of Hetauda is $230.4 \mathrm{TJ}$ and will be increased to $333.5 \mathrm{TJ}$ for the accounting year 2018 and 2035 respectively.
\end{abstract}

Keywords: Demand, three wheeler vehicle, GHG emission

\section{Introduction}

The transport sector is one of the major consumers of fossil fuels and uses a significant amount of the global energy supply[1]. All over the world, transportation has been an important sector, which accounts major portion of the global greenhouse gas emission growing in faster pace to cater economic activities. Transport alone was responsible for around $17 \%$ of global energy related CO2 emissions in 2015[2].Almost three-quarters of the emissions from transport were due to road. The development of electric vehicles (EVs) is an emergent solution to green the existing transportation systems and to reduce the issues of climate change. In recent years, scholars, policy-makers, and the general public in many parts of the world have become increasingly concerned over health and environmental damages associated with air pollution. Many industrialized countries have revised the policies to encourage the use of alternative-fuel vehicles. Also, motivated by the increasing environmental concerns and the available resource limitations of oil, the automobile industry has continued to develop different alternative fuel vehicles. In the United States, for example, California, New York and a few other states had mandates that required $10 \%$ of all motor vehicles sold after 2003 to be zero-emissions vehicles or, in other words, EVs. California, in particular, provides certain sales credit to encourage the purchase of EVs [3]. As urban transport is among the most important contributors to urban air pollution, this concern has led to a heightened interest in Electric Vehicles (EVs) as well as other environmentally friendly alternative forms of transport. Due to the increase in number of fossil fuel based vehicles in Nepal and the rapidly changing global fuel price, every year huge amount of national earning is spent on the import of petroleum which is not even balanced by the summation of export earnings [4]. In Nepal, transport sector consumes about $63 \%$ of total imported petroleum fuel [5] and the majority of this fuel is consumed by vehicles in Kathmandu valley. The import of petroleum fuel, which was $34 \%$ of the total annual earnings from the export in 2000/01, has increased to $143 \%$ of the total annual earnings from the export in 2012/2013 [6]. 


\section{Problem Statement}

Motor vehicle numbers have grown more rapidly in the cities which increase traffic congestion and environmental emissions daily. In fight against air pollution and greenhouse gas emissions, the electrification of the transport sector is an important goal because widespread electrification would greatly improve the quality of the air we breathe. And in fact, switching to electric vehicles has also been a core target of the Ministry of Forests and Environment since 2015, when Nepal's Nationally Determined Contribution was established. Nepal has a comparative advantage in terms of production of its own hydroelectricity, a local energy resource, with a huge potential to replace imported fossil fuel in upcoming days resulting the energy security of country. Also, EVs are the cleaner, greener, and quieter alternative money saving and cheaper in the long run and is dependent on domestic energy sources of Nepal. However, researchers are working on improved battery technologies to increase driving range and decrease recharging time, weight, and cost. These factors will ultimately determine the future of EVs [7].

\section{Objectives}

The main objective of the study is to develop future three wheeler electric vehicle energy scenario and energy security of Hetauda from 2018 to 2035.

\section{Literature Review \\ 4.1 Brief Description of Hetauda}

The city is situated in a unique geographical structure called Doon, giving it a valley-like geography. It is surrounded by mountains, with the Mahabharata Range to the north and the Sivalik Hills to the south. The rivers Rapti, Samari, and Karra run through the city and flow southwest to meet the Narayani, one of the bigger rivers of Nepal.

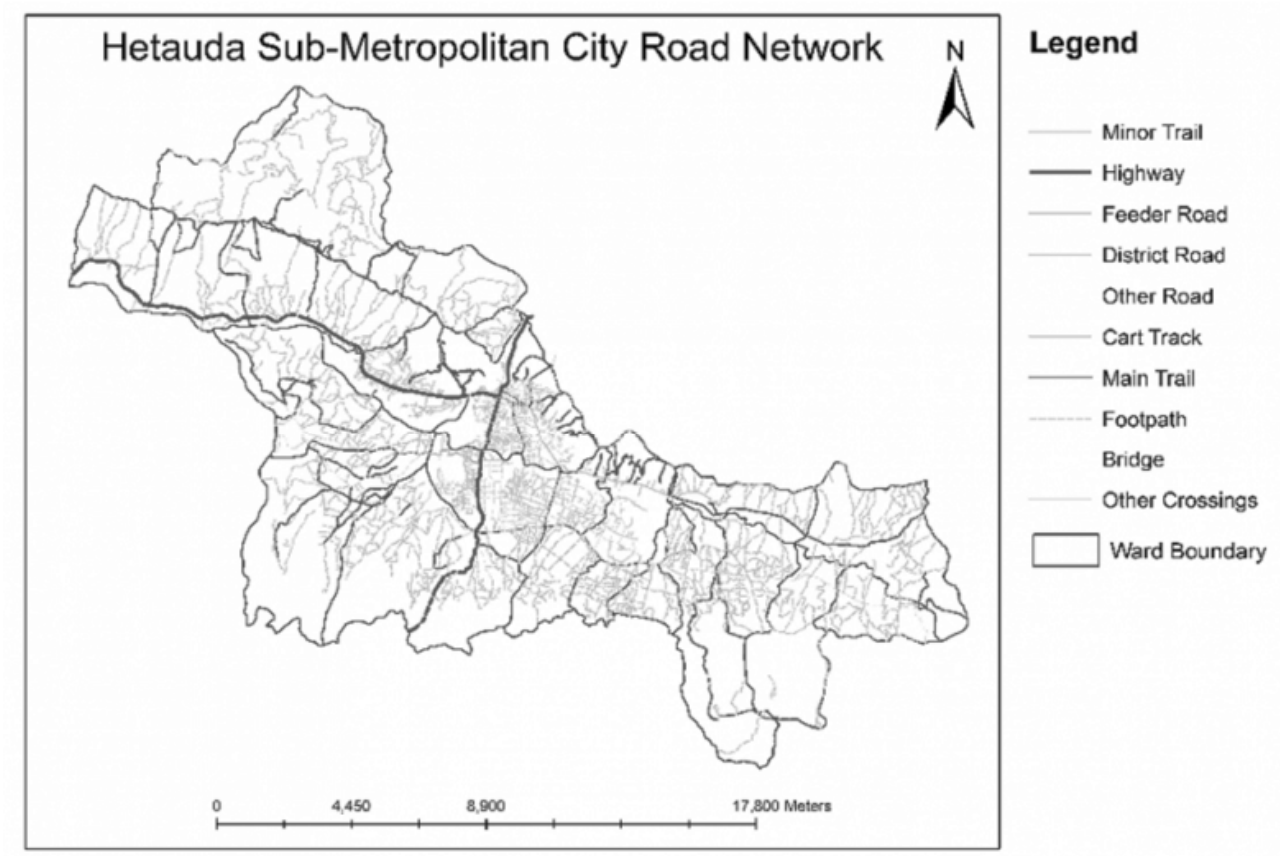

Fig 1 Hetauda Sub-Metropolitan City Road Network [8]

It is properly situated at the central of the Makwanpur district. It lies in the $27^{\circ} 25^{\prime} \mathrm{N}$ latitude and $85^{\circ} 02^{\prime}$ E longitude and is situated at a level of $300-390 \mathrm{~m}$ above the sea level. The total area of the city is 261 $\mathrm{km} 2$ where around $254 \mathrm{~km} 2$. (97\%) is land and the remaining $7 \mathrm{~km} 2(3 \%)$ consists of water. Boundary: East: Chhatiwan V.D.C West: Manahari, Haandikhola and Sarikhet V.D.C North: Naamtaar, Bhainse and MakwanpurgadhiV.D.C South: Bara and Parsa District, the city is surrounded by three rivers 
the Rapti to the west, the Samari to the north, and the Karra to the south and is part of an important industrial regions[9]. The settlement developed because of its location along the Tribhuvan Highway, and was later linked to another major national thoroughfare: the Mahendra Highway, also known as the East-West Highway. According to 2018 census, Hetauda has the total population of 84,775. It was awarded as the cleanest city of Nepal in the year 2016 and 2017.

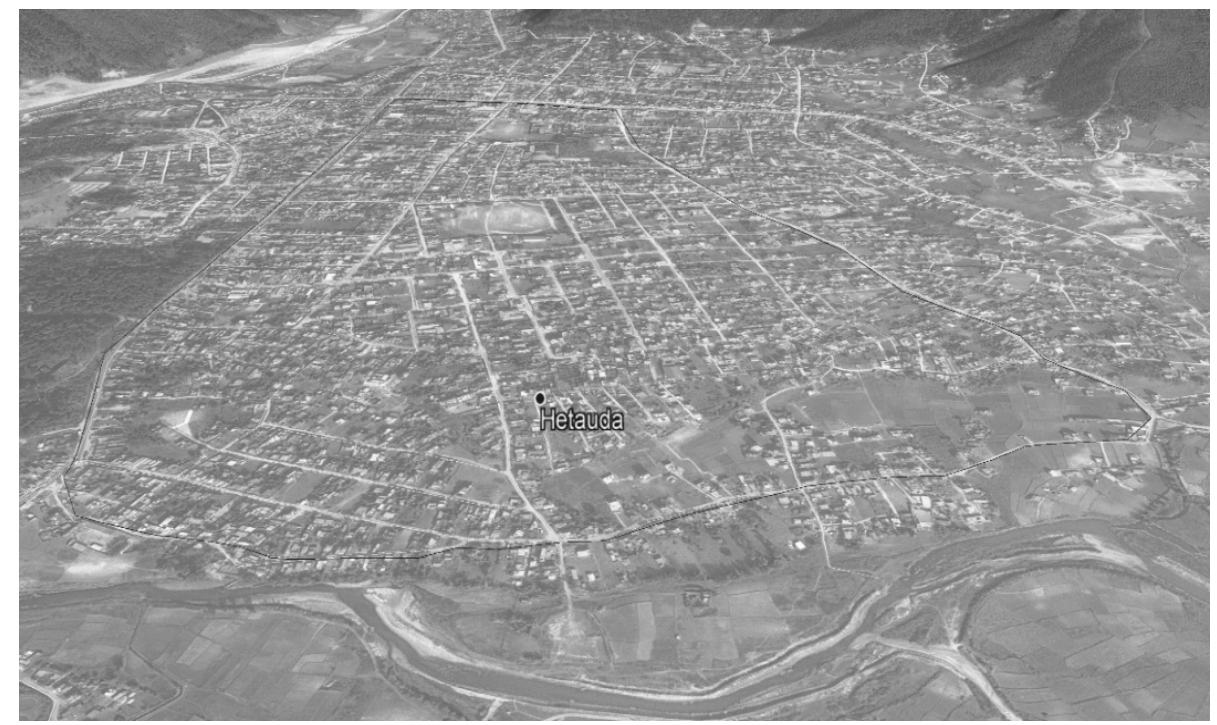

Fig 2: Hetauda city GIS view [10]

\section{Gap}

At present, there are very limited research in the field of examining the status and effects of policies in the development of electric vehicles in Nepal. This study is focused on understanding the status of electric vehicle development and examining the role of government policies, vehicle technical features and the development of infrastructure in the private EV promotion in Kathmandu Valley, rather than the exact prediction of the future EV population Hetauda is going to be province 2 capital city of Nepal and its population is projected to double by 2030[11] and considered as second largest among cities of Nepal according to population. About $35.40 \%$ of the total vehicles registered in the country are registered in the Narayani zone. Introduction of policies favorable to battery powered vehicles could at least replace this incremental rate by EVs. Reduction in purchase and operation costs, charging duration can create a huge acceptability of electric vehicles. Similarly, construction of charging infrastructure around could provide solution to worries of the general public while purchasing an EV. The study has been undertaken to growth rate of electric vehicles based on public and developer's aspects and to promoting EVs in Nepal indifferent scenarios to come up with policy suggestions and recommendations.

\section{Research Methodology}

The methodology followed for doing the study can be understood from the flowchart drawn and the explanations followed. Fig. 3 shows methodological flow chart. 


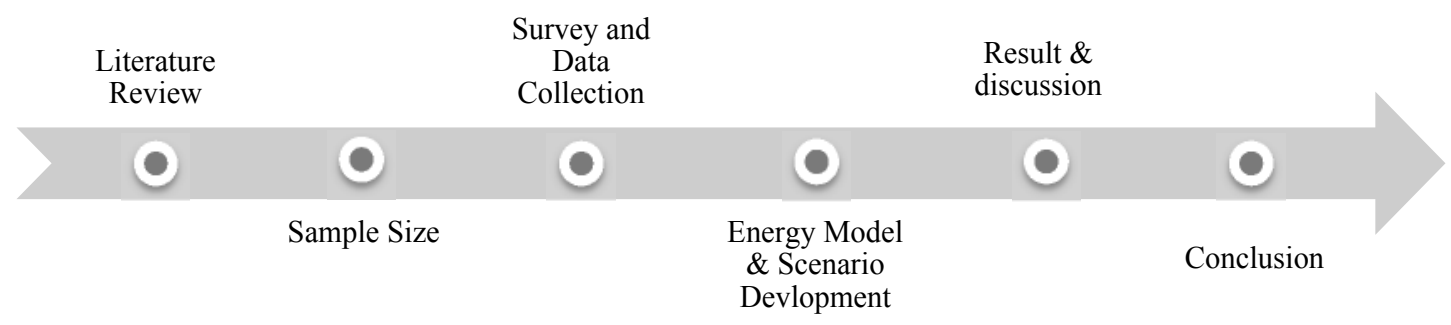

Fig 3 Flow Chart for methodology adopted

\section{Scenarios Description}

Scenario planning is a useful approach to design and plan long term future energy demand and supply requirements. For the scenario analysis, 2018 was taken as a base year. The future final energy demand of Hetauda was projected to the year 2035. Population and Passenger kilometer is the key drivers of the energy demand. Table 1 shows simple comparative study of all three scenarios.

\begin{tabular}{|c|c|c|}
\hline \multicolumn{2}{|c|}{ Scenario name } & Description \\
\hline BAU & $\begin{array}{l}\text { Business-as- } \\
\text { usual Scenario }\end{array}$ & $\begin{array}{l}\text { - Population growth rate } 2.2 \% \\
\text { - It is the extension of the current activity in the absence of } \mathrm{CDM} \\
\text { project intervention }\end{array}$ \\
\hline $\begin{array}{c}\text { ETRM } \\
100\end{array}$ & $\begin{array}{c}\text { Electric Tempo } \\
\text { Replacement by } \\
100 \%\end{array}$ & $\begin{array}{l}\text { - Population rate remains constant throughout the study period. } \\
\text { - Traditional energy sources like fuel gradually replaced by clean } \\
\text { and modern source i.e. electricity. } \\
\text { - The three wheeler electric will be introduce in } 2017 \text { and its share } \\
\text { will gradually go on increasing and will reach to } 100 \% \text { in } 2035\end{array}$ \\
\hline $\begin{array}{c}\text { ETRM } \\
75\end{array}$ & $\begin{array}{c}\text { Electric Tempo } \\
\text { Replacement by } \\
75 \%\end{array}$ & $\begin{array}{l}\text { - The electric will be introduced in } 2017 \text { and its share gradually } \\
\text { goes on increasing and will reach to } 50 \% \text { in } 2035 \text {. } \\
\text { - To know the consequences if the decision is made only for } 75 \% \\
\text { replacement }\end{array}$ \\
\hline
\end{tabular}

Table 1 Scenario Summaries

\section{Results and discussions}

\subsection{Energy Demand for different years(2018 to 2035)}

Energy demand of Hetauda is $230.4 \mathrm{TJ}$ and is increased to $333.5 \mathrm{TJ}$ for the accounting year 2018 and 2035 respectively. Fig.4 shows the share of final energy demand by fuel type in 2018 and 2035, i.e. the composition of the electric and gasoline are $29.7 \mathrm{TJ}$ and $200.7 \mathrm{TJ}$ in 2018 and 43TJ, $290.5 \mathrm{TJ}$ respectively for the year 2035. Now when ETRM100 then this scenario is seen in fig 5.It is seen that the total energy demand was $75.5 \mathrm{TJ}$ and their composition of energy demand for the electric will be 75.5TJ and that of gasoline will be 0. Similarly when ETRM 75 then this scenario. It is seen that the total energy demand was $225.5 \mathrm{TJ}$ and their composition of energy demand for the electric will be $56.6 \mathrm{TJ}$ and that of gasoline will be $168.9 \mathrm{TJ}$.

\subsection{GHG Emission}

The Green houses gases taken into account in this study include carbon dioxide, nitrous oxide and methane only. The one hundred year Global Warming Potential is considered in this study. The GWPs show their relative strength to have effect in Global Warming Potential. Green houses gases taken into account in this study include Carbon dioxide, nitrous oxide and, methane only. Other greenhouse gases 
like non-methane volatile organic compounds (e.g. olefins, ketons, aldehydes) which are the product of incomplete combustion. They are volatile under ambient air conditions. The below fig 6 and 7 shows the different scenario result for GHG emission. Here the carbon dioxide is produces for the year 2018 was 13.8 thousand metric tons and will be 19.90 thousand metric tons on current time for 2035 . If the ETRM 100 is utilized then carbon dioxide will be reduce to 0 where as if it's ETRM 75 then it will rise to 11.6 thousand metric tons. Since nitrous oxide is also another GHG emission gas for current time year then it is produce 0 and for 2035 it is 0.1 thousand metric tons. For nitrousoxide will be reduce to 0 for both the scenario. Similarly methane is produces for the year 2018 was 0.1 metric tons and will be 0.1 thousand metric ton on current time for 2035. If ETRM100 and ETRM 75 then methane will be reduce to 0 .

\section{Scenario Results}

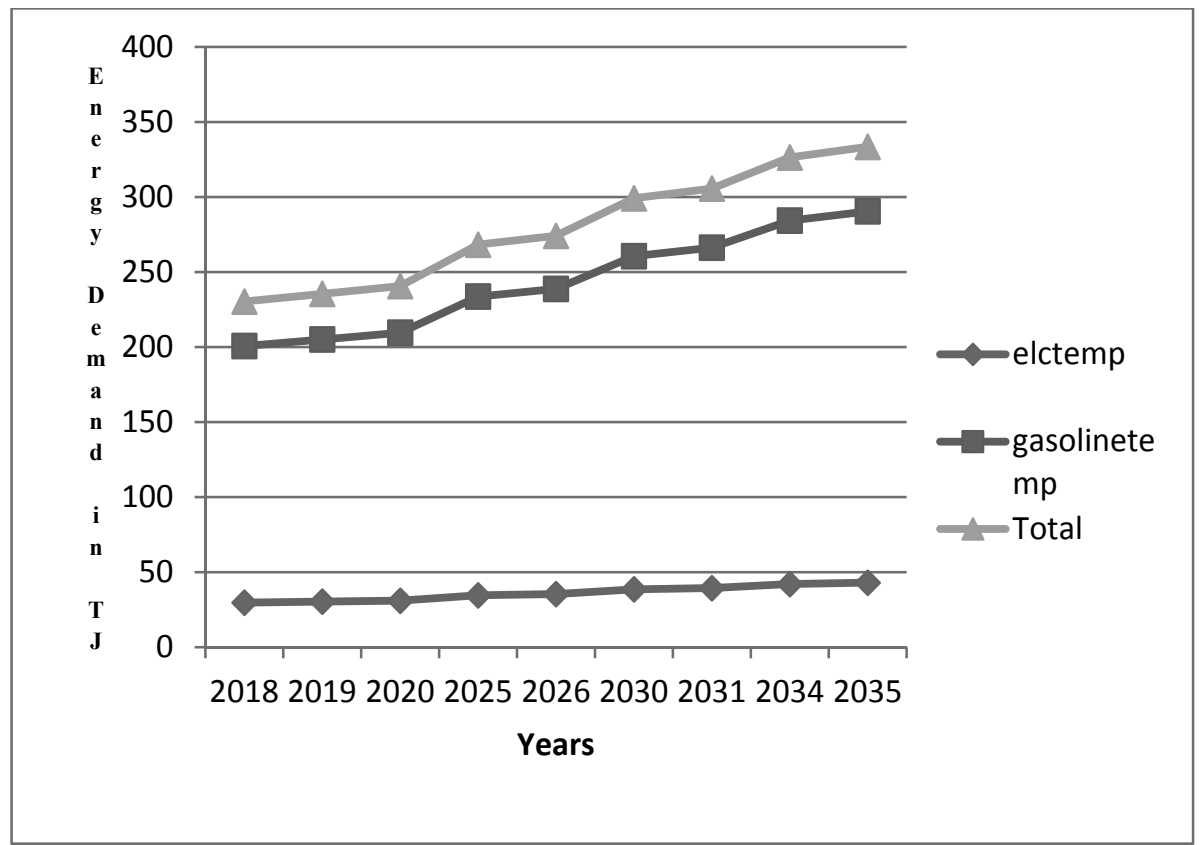

Fig 4 BAU Scenario Summaries for Energy Demand

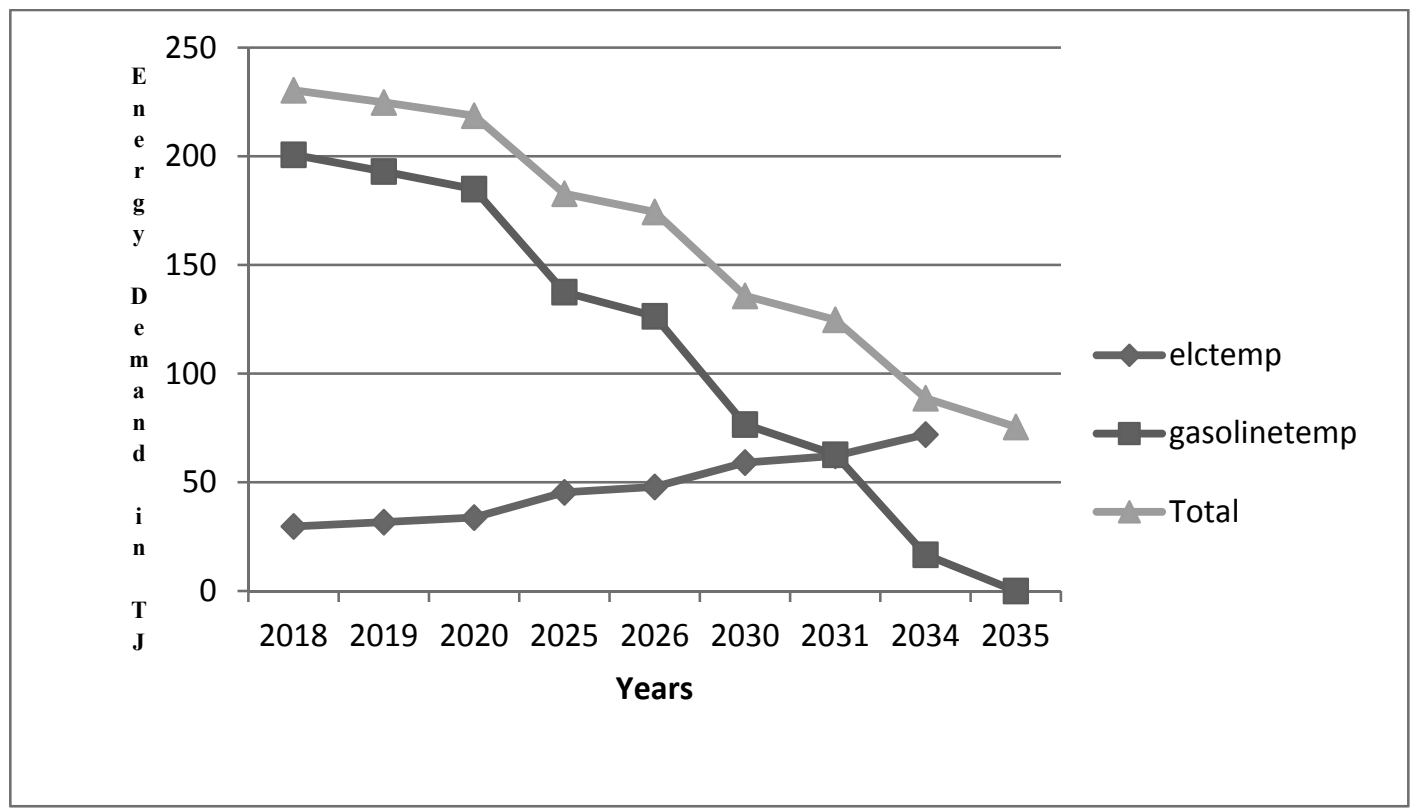

Fig 5 ETRM 100 Scenario Summaries for Energy Demand 


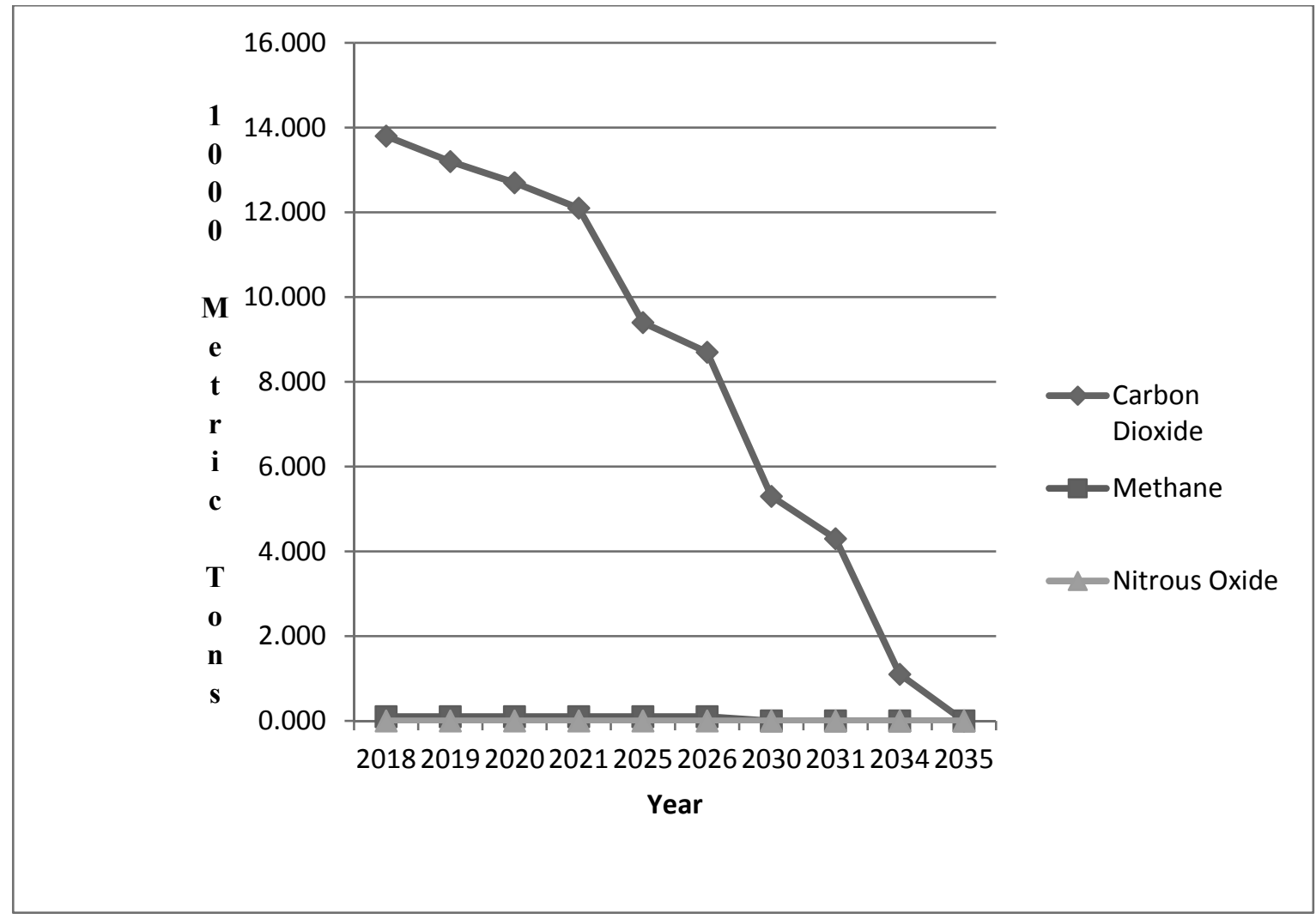

Fig 6 BAU Summaries for GHG Emission

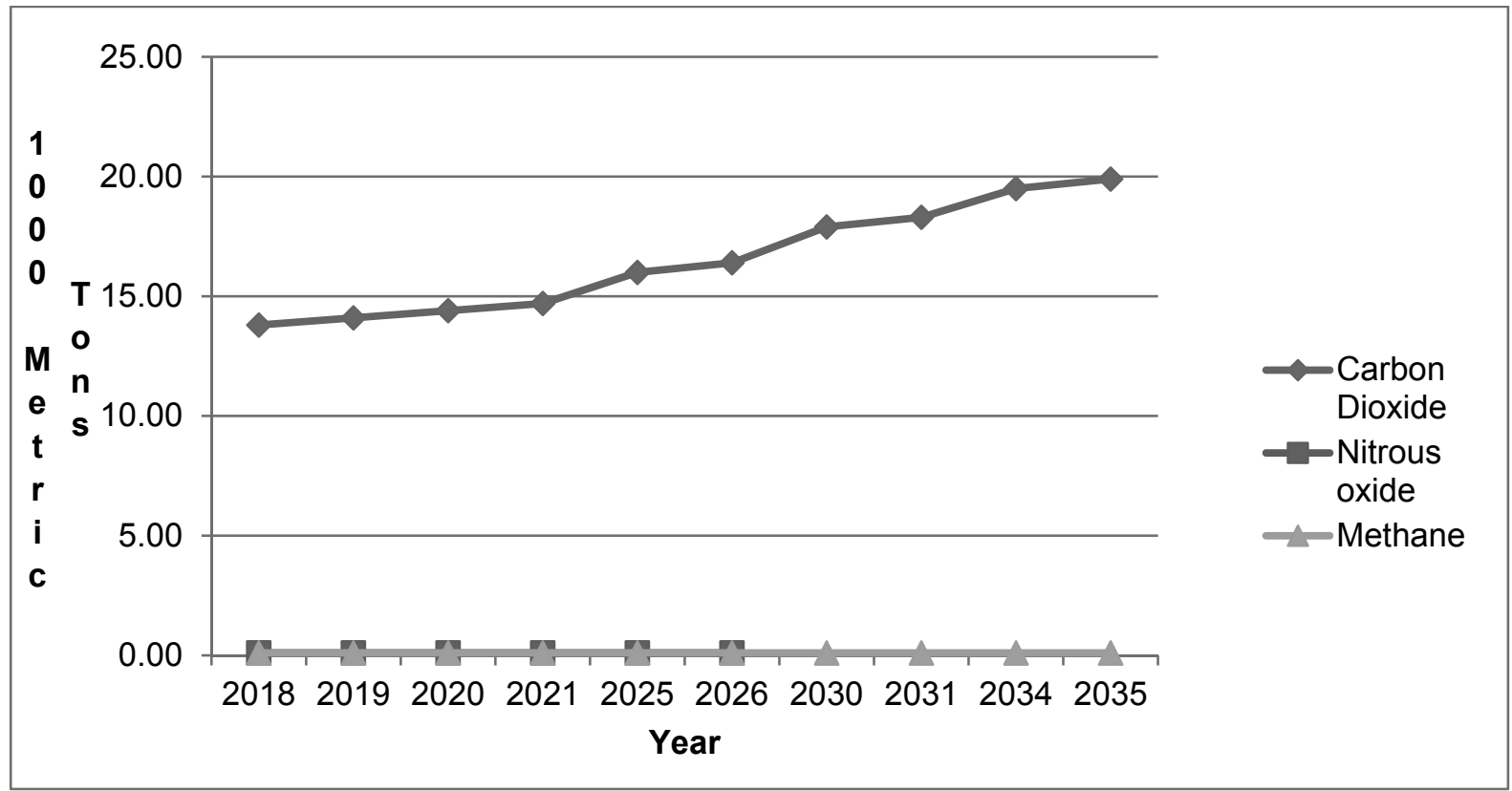

Fig 7 ETRM 100 Scenario Summaries for GHG Emission 


\section{Conclusion}

The energy system and its development prospects are fundamental to every economic activity. Thus, a sufficient energy supply is a precondition for economic development. To meet sustainable development various indicators have been derived to evaluate each scenario. According to evaluation results, the current pattern of energy demand would put huge pressure not only in energy requirement but also national economy. An effective policy is the imperative requirement in current situation. The policy should be driven by strategies for utilization indigenous renewable resources instead of importing petroleum products. The effective measure could contribute to the transformation of the energy system towards a more sustainable development meeting the international and national commitment of Nepal towards climate change.

\section{Recommendation}

A study has some shortcomings and limitations due to various factors. During the study certain assumptions were made. With the reference to this study, further studies could be done. The survey is based on pure geographic sampling bound by administrative boundaries. Pure consumption analysis can yield more descriptive energy consumption pattern and effect of energy transition. The detail study can be carried out to reduce the impact and control of lead discharge in environment from EV batteries. Research related to introduction of vehicles running from other types of energy like fuel cells, ethanol and bio-diesel could be done in future as well as non-energy sectors such as enteric fermentation can be undertaken as further study. Also its impact to the human health and environment can be analysed.

\section{Acknowledgments}

The authors are grateful to Stockholm Environment Institute for providing the Long range Energy Alternatives Planning System (LEAP) tool for free of cost.

\section{References}

1. D. V. Bhatt, "Estimation of amount of co2 reduction by safa Tempo( electric three wheelers ) in Kathmandu valley," 2013.

2. EEA, "Trends in Global CO2 emission," European Environmental Agency, Netherlands, 2016.

3. B. \&. Joshi, 2004.

4. Ministry of Industriy, Commerc \&Supplies, 2012.

5. NOC, "Annual Report," Nepal Oil Corporation, 2013.

6. MoF, "Economic Survey Report," Ministry of Finanace, Kathmandu, 2014.

7. Larminie and J. \&Lowry, Electric Vehicle Technolgy, England, 2003.

8. no. Department Of Transport Management.

9. District climate and energy plan ,Makwanpur District, no. District Development Committee,Makwanpur, 2011,April.

10. no. Google.

11. Central Bureau of Statistics, 2012. 